


\section{Data centre opportunities in the Nordics}

An analysis of the competitive advantages

Jakob Dybdal Christensen, Jens Therkelsen, Ivo Georgiev and Henrik Sand

TemaNord 2018:553 
Data centre opportunities in the Nordics

An analysis of the competitive advantages

Jakob Dybdal Christensen, Jens Therkelsen, Ivo Georgiev and Henrik Sand

ISBN 978-92-893-5898-9 (PRINT)

ISBN 978-92-893-5899-6 (PDF)

ISBN 978-92-893-5900-9 (EPUB)

http://dx.doi.org/10.6027/TN2018-553

TemaNord 2018:553

ISSN 0.908-6692

Standard: PDF/UA-1

ISO $14289-1$

(c) Nordic Council of Ministers 2018

Cover photo: Shutterstock

Print: Rosendahls

Printed in Denmark

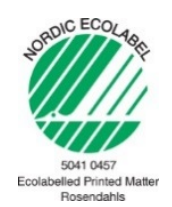

\section{Disclaimer}

This publication was funded by the Nordic Council of Ministers. However, the content does not necessarily reflect the Nordic Council of Ministers' views, opinions, attitudes or recommendations.

\section{Rights and permissions}

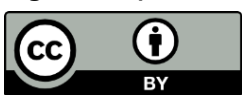

This work is made available under the Creative Commons Attribution 4.0 International license (CC BY 4.0) https://creativecommons.org/licenses/by/4.0

Translations: If you translate this work, please include the following disclaimer: This translation was not produced by the Nordic Council of Ministers and should not be construed as official. The Nordic Council of Ministers cannot be held responsible for the translation or any errors in it.

Adaptations: If you adapt this work, please include the following disclaimer along with the attribution: This is an adaptation of an original work by the Nordic Council of Ministers. Responsibility for the views and opinions expressed in the adaptation rests solely with its author(s). The views and opinions in this adaptation have not been approved by the Nordic Council of Ministers. 
Third-party content: The Nordic Council of Ministers does not necessarily own every single part of this work. The Nordic Council of Ministers cannot, therefore, guarantee that the reuse of third-party content does not infringe the copyright of the third party. If you wish to reuse any third-party content, you bear the risks associated with any such rights violations. You are responsible for determining whether there is a need to obtain permission for the use of third-party content, and if so, for obtaining the relevant permission from the copyright holder. Examples of third-party content may include, but are not limited to, tables, figures or images.

Photo rights (further permission required for reuse):

Any queries regarding rights and licences should be addressed to:

Nordic Council of Ministers/Publication Unit

Ved Stranden 18

DK-1061 Copenhagen K

Denmark

Phone +4533960200

pub@norden.org

\section{Nordic co-operation}

Nordic co-operation is one of the world's most extensive forms of regional collaboration, involving Denmark, Finland, Iceland, Norway, Sweden, and the Faroe Islands, Greenland and Åland.

Nordic co-operation has firm traditions in politics, economics and culture and plays an important role in European and international forums. The Nordic community strives for a strong Nordic Region in a strong Europe.

Nordic co-operation promotes regional interests and values in a global world. The values shared by the Nordic countries help make the region one of the most innovative and competitive in the world.

The Nordic Council of Ministers

Nordens Hus

Ved Stranden 18

DK-1061 Copenhagen K, Denmark

Tel.: +4533960200 www.norden.org

Download and order Nordic publications from www.norden.org/nordpub 



\section{Contents}

Executive summary

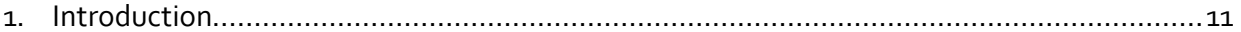

1.1 An increasing demand for data services .................................................... 11

2. Development of the data centre market .................................................................. 15

$2.1 \quad$ Development of the Nordic market ................................................................ 15

2.2 Development of the FLAP-D market ........................................................... 20

3. Strengths and value proposition of the Nordic region ................................................23

3.1 Ranking of most important factors for site selection .......................................27

3.2 Value proposition of the Nordic region ...................................................... 30

4. A growing opportunity for investment in the Nordics ............................................ 35

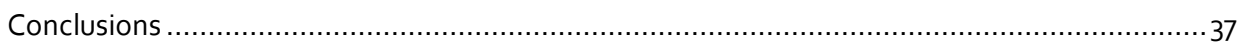

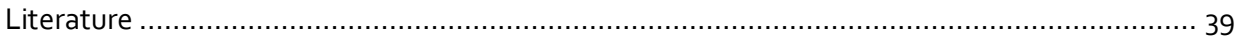

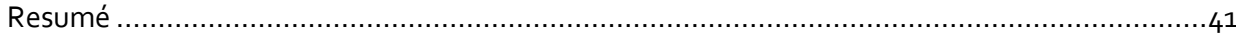

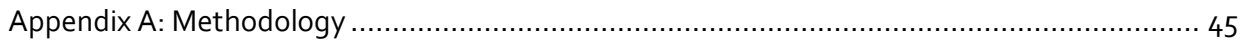

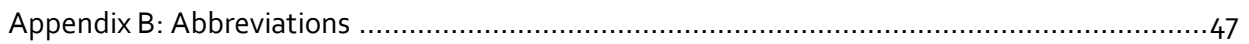




\section{Executive summary}

The Nordic region is a global leader in the digital economy, and the Nordic countries Denmark, Sweden, Norway, Finland and Iceland have an outstanding "human capital" with above $90 \%$ of the population being regular internet users.

In recent years, the Nordic region has attracted significant investment in new data centres. This includes massive investments from cloud and hyperscale investors like Facebook, Google, AWS and Apple. Facebook has recently announced potential expansions in both Sweden and Denmark, whilst AWS is constructing three new data centre sites near Stockholm. Apple is working on two sites in Denmark of tremendous scale, whilst Google is expanding its operations in Finland and has acquired land for potential future development in Denmark and Sweden. In Norway, Microsoft has announced investment in two cloud regions, and private and public stakeholders are developing large facilities. Iceland is already home to some of the world's largest highperformance computing and blockchain data centres due to its abundance of costefficient renewable energy sources and a cool climate. Additionally, global and European colocation investors like Equinix and Interxion are expanding existing sites, and players like Digiplex with a more Nordic focus are growing further.

To capture the opportunity of the Nordic data centre development, this study analyses the current state of the investment climate. It estimates the investment potential throughout the Nordics and describes the development of the data centre market in the Nordics compared to the FLAP-D regions. It also identifies the strengths and value proposition of the Nordic region by assessing and ranking the most important factors, which investors currently consider for data centre site selection according to four data centre segments. The study finds that there is an exceptionally strong match between the most important factors and the parameters where the Nordic markets are perceived as very attractive. In other words, the study presents the Nordic region as very attractive according to the most important factors for site selection, and thus a strong case for continued data centre investment.

Against this background and the growth of the global data centre market, COWI estimates that the data centre construction market could attract annual investment in the order of EUR 2-4.3 bn. in the Nordic countries by 2025. This corresponds to construction of sites capable of hosting an additional power capacity ranging between 280-580 MW per year over the same period.

While the study considers a long list of 16 key factors influencing the site selection investment decision, COWI found that the most important factors are: 
1. "Reliable power supply" and "international data connectivity";

2. "Low energy prices";

3. "Political stability";

4. "Time-to-market", "abundance of energy and other resources", "competent workforce" and "natural disaster-free climate".

At the same time, it appears that the Nordic region is perceived and ranked as very attractive in terms of reliable power supply, low energy prices, political stability, timeto-market, abundance of energy and other resources, and space scalability. Thus, the value proposition of the Nordic region as an attractive location for data centres emerges in the following five categories:

1. Reliable power supply, as the Nordic power grid is extremely reliable without power outages, which lowers the risk of interruption of the ICT services that data centres deliver;

2. Low energy prices, supported by a well-functioning and competitive electricity market, which lowers significantly the operational costs;

3. Political stability, characterized with high transparency, predictability and consensus in decision making, which reduces the risks of long term investments;

4. Faster time-to-market, supported by an easy-to-do business environment with less procedures and quick approvals in the planning process, which saves time and costs;

5. Abundance of energy and other resources, such as renewable energy sources e.g. hydropower, geothermal power, biomass and wind.

In terms of data centre segments, the Nordic region appears very attractive for investment in the hyperscale and cloud segments regarding the most important siteselection factors. The time to market, space scalability and the energy related factors are also very important to the hyperscalers and the Nordic region scores very high on all of them as well.

The Nordic region also appears attractive for investment in the colocation and enterprise segments considering the most important site-selection factors. The major difference between hyperscalers and cloud on the one side, and colocations and the enterprise data centre segments on the other, is that the latter segments score the importance of most factors lower. This implies that even though the Nordic region is attractive on those parameters, they are less important for those segments. This provides an opportunity for the Nordics to attract additional colocation and enterprise data centres, in which we already follow an increasing number of activities. For instance, to HPC (high performance computing) data centres and colocation investors specialized in sustainability, the Nordics appear very attractive. Moreover, with the rise of IoT (Internet of Things) and autonomous cars, we can expect opportunities for "edge" facilities in the metropolitan Nordic areas. 
Further underpinning the steep development of the Nordic region in pursuit of becoming a global hub for data centre investments, a focus could be on improving factors such as:

- International connectivity - proximity to international internet exchanges and other central peering points is seen as a key decision factor for attracting data centre investments. Improving the perception among investors by highlighting facts regarding the Nordic connectivity is relevant. For example upgraded submarine cables to the US planned for 2019 from the Danish west coast and the Norwegian south coast. The Stockholm - Finland link Eastern Light is in the making. Moreover, existing fibre cables provide links to the UK - from Denmark and Norway and new routes being planned. Finland connects directly to continental Europe through the C-lion cable to Germany, and Denmark connects directly to the Netherlands through the COBRA link. Iceland is positioned between North America and Europe and has connections to both continents. Additionally, access to a polar fibre route from China is expected to cut Asia to Europe latency by half, and could transform the Nordics as a central East/West connectivity hub. In the coming years, we may be seeing the quickest routes to moving traffic globally via the North;

- Competent workforce - availability of sufficient numbers of technically skilled workforce is pivotal when establishing a hub region. As the data centre industry is emerging in the Nordics, the demand of labour also increases. With the emergence of the data centre value chain, more and more local technicians become employable. For example some Nordic countries have the highest proportions of ICT specialists in employment in Europe;

- Continued harmonisation of national rules and processes in the Nordic region - e.g. processes for zoning, building permits, the rules for load shedding of transmission connected electricity customers, environmental attributes from procuring energy from renewable resources. Harmonisation strengthens even further the Nordic region as a whole and improve its ability to attract and migrate capacity from DC owners currently operating outside the Nordics to the Nordics. This support an even faster time to certainty and direct access to potential sites (sites already zoned with multiple grid connections and sufficient capacity within a defined short period of time). 


\section{Introduction}

This study is prepared by COWI for the Nordic Council of Ministers. It is commissioned by the five Nordic investment promotion agencies: Denmark (Invest in Denmark), Sweden (Business Sweden), Norway (Innovation Norway), Finland (Invest in Finland) and Iceland (Promote Iceland).

The report provides an analysis of the market outlook for data centre investment and outlines the value proposition of the Nordic region. It maps data centre segments according to investment in the Nordic and Frankfurt-London-Amsterdam-Paris-Dublin (FLAP-D) markets. It also maps key data centre players and presents attraction factors for current and potential data centre investments. Finally, it describes advantages for locating a data centre facility in the Nordic region.

The study analysis is based on data collected through a desk review and $30+$ interviews with key data centre owners, operators and experts.

\subsection{An increasing demand for data services}

As the world goes online, increasing amounts of data are generated. Data development grows exponentially, creating a significant need for construction of digital infrastructure. Numerous new data centres are built around the world to serve the growing need for ICT services. Data creation, collection, storage and analysis, driven by digitalization and the growing number of smart consumer devices, extended use of data-heavy media, robotic factories, industrial and vastly distributed loT, use of AI/ML/DL and other technologies like the rise of autonomous vehicles are creating a tremendous potential for data centre development around the world, Europe and the Nordics.

The growing demand for data leads to an increased need for power capacity in data centres and provides potential investment opportunities. These developments are presented below.

As visible in Figure 1, the daily data generation per capita is set to increase tremendously to $72 \mathrm{~GB}$ in 2025 (from approximately $4 \mathrm{~GB}$ in 2018). 
Figure 1: Global increase of daily data generation by 2025 (in GB per capita)

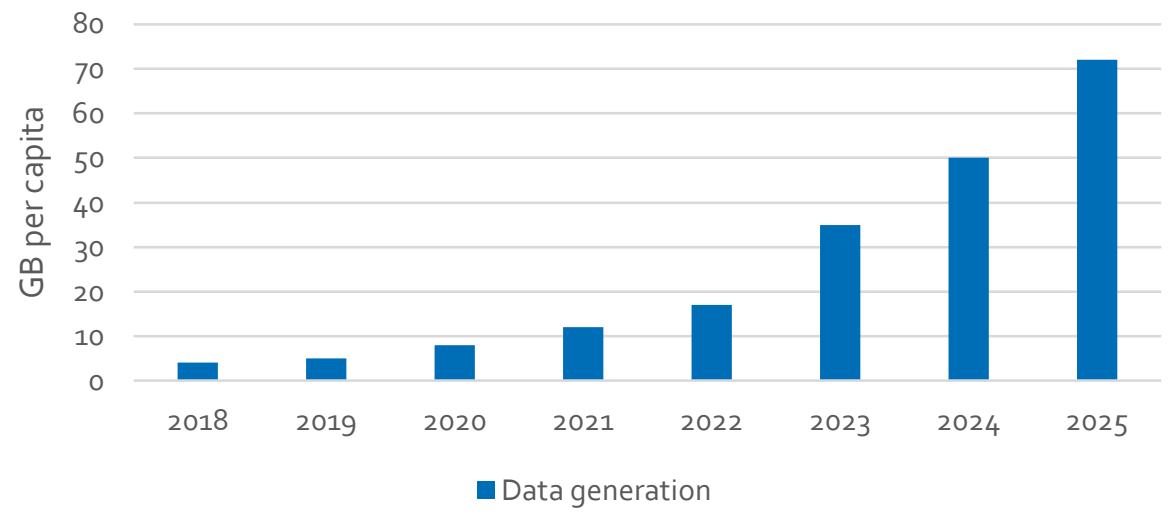

Source: Huawei, Total consumer power consumption forecast (2017).

As a result of the increase in data generation (and also communication), the outlook for global power capacity of data centres is set to increase to above 80 GW by 2025 as illustrated in Figure 2.

Figure 2: Outlook for global power capacity of data centres (in GW)

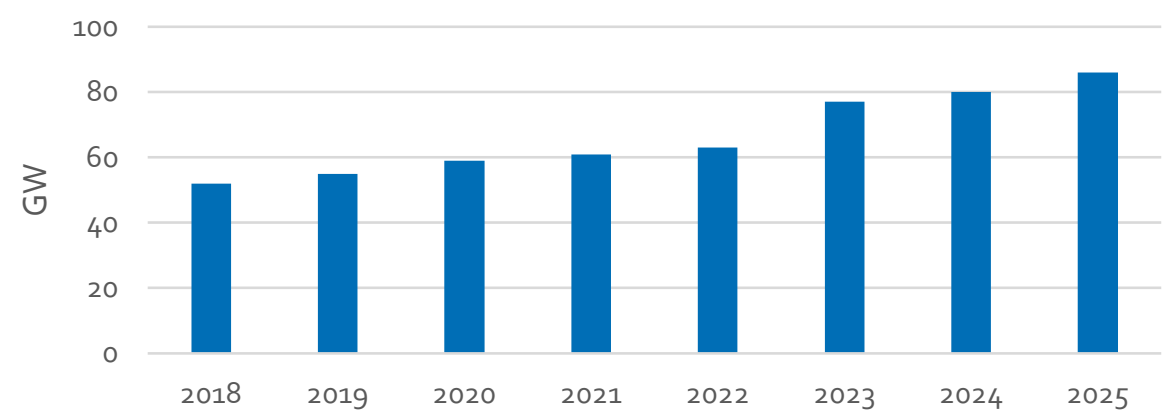

Source: COWI, Analysis of Data Centre Investment Opportunities in the Nordic Countries (2018).

COWl estimates that this can generate annual revenues in the range of EUR 25-43 bn. to the construction sector globally by 2025 , as illustrated Figure 3 . 
Figure 3: Outlook for global construction investment in data centres (in EUR bn.)

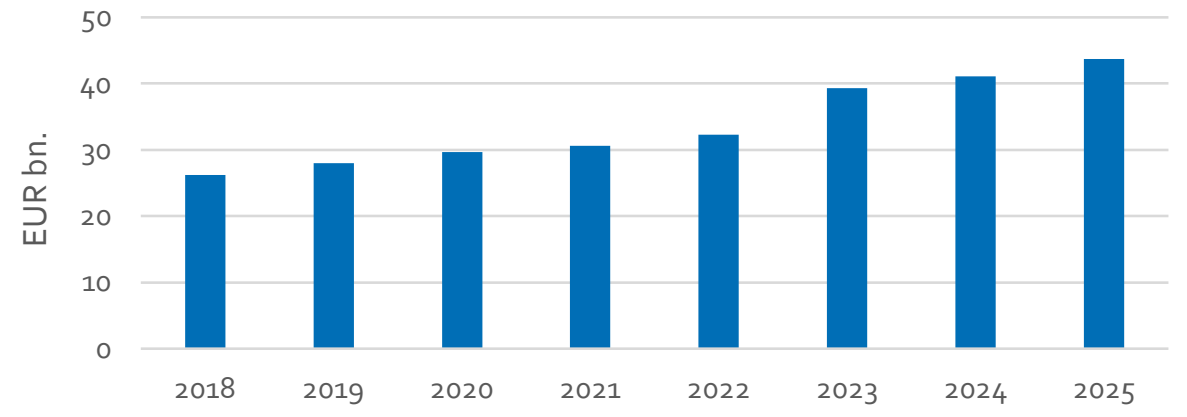

Source: COWI, Analysis of Data Centre Investment Opportunities in the Nordic Countries (2018). 


\section{Development of the data centre market}

\subsection{Development of the Nordic market}

Against the background of a growing global demand for data generation and communication, the Nordic region has attracted significant data centre investments. For example, after Google and Facebook entered the region in 2009 and 2011, the Nordic countries have become a preferred site location by an increasing number of data centre investors.

The Nordic site-investment "boom" has evolved even further in recent years with an increasing number of projects with large data storage capacity under construction or planning. As a result, the total established and already installed data centre capacity $\left(\mathrm{m}^{2}\right.$ and MW) has not yet capitalized in the same magnitude as heritage locations in Europe, such as the FLAP-D region. However, the size of the land being purchased $(\mathrm{Ha})$ and the power capacity (MW) in the Nordic countries is set to make a substantial contribution in the European market, if utilized by the investors.

The segmentation of data centre investment types is also developing rapidly. For the purpose of simplification under this study, we have segmented four types of data centre investment; 1 ) hyperscale (build for purpose) 2 ) cloud (build for purpose) 3) colocation and 4) enterprise.

Figure 4 below ilustrates the 2018 development in the Nordic countries. It presents the locations of significant data centre investment which is already operational, under construction, in planning or where land has been acquired for potential planning. It should not be viewed as a complete mapping, but a visualization of the current investment landspace. As the figure is intended to provide only an overview, there is a large number of smaller colocation and enterprise data centers which are not included in this map. 
Figure 4: Mapping of significant investment in Nordic data centres

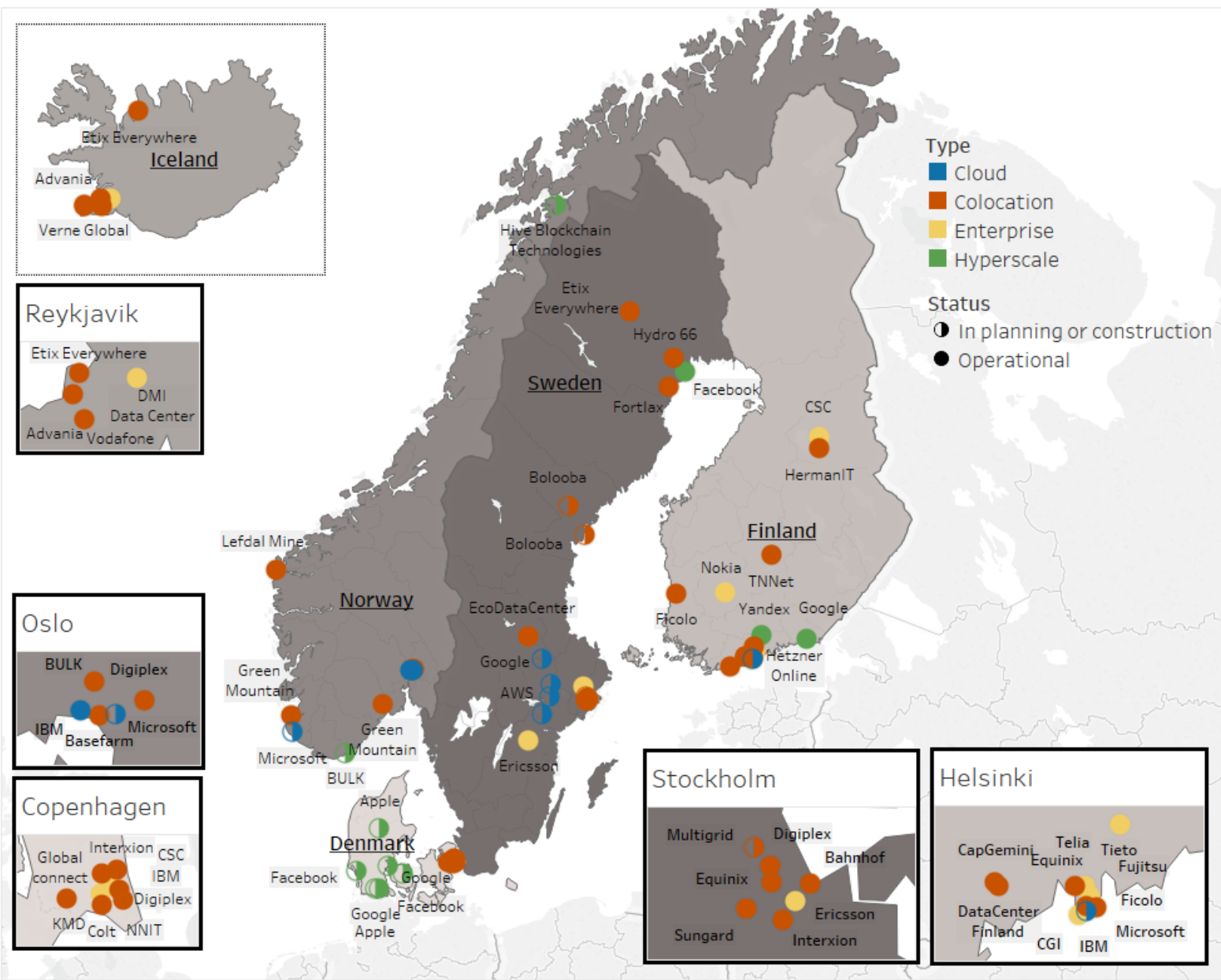

Note: Please note that the Facebook facility near Esbjerg, Denmark is not officially announced.

Source: COWI (public sources).

In addition to Table 1, below we provide a more detailed overview of current data centre investment projects announced in the Nordic region, building on the outcomes of a desk study. The overview presents current data centre investment and indicates a strong traction in the region from foreign direct investors in the self-build hyperscale and cloud segments (with a growing number of entities within the colocation segment). The four segments are desribed below.

\subsubsection{Hyperscale (Build for purpose)}

These are large data centre facilities above $20 \mathrm{MW}$, owned and typically operated by the company they support. They are usually service platforms for social media, search engines, communication \& entertainment, VR/AI/ML, and e-commerce. These data centres are normally located close to the power grid, preferably by a transformer 
connection points with physical redundancy, in areas with power abundancy, preferably with large land plots available for future scalability. An overview of the Nordic investment in hyperscale build for purpose data centres is exemplified below.

Table 1: Overview of Nordic investments in Hyperscale, build for purpose*

$\begin{array}{ll}\text { Current investments } & \text { Potential investments } \\ \begin{array}{l}\text { Facebook, Luleå - Sweden (2 DCs installed, potential extension } \\ \text { announced) }\end{array} & \text { Baidu } \\ \text { Yandex, Mäntsälä - Finland (1 DC installed) } & \text { Tencent } \\ \begin{array}{l}\text { Apple, Viborg - Denmark (1 DC under construction, space for additional } \\ \text { multiple buildings on lot) }\end{array} & \text { Xiaomi } \\ \begin{array}{l}\text { Facebook, Odense - Denmark (2 DCs under construction, space for } \\ \text { additional buildings on lot) }\end{array} & \text { Samsung } \\ \begin{array}{l}\text { Apple, Aabenraa - Denmark (planned for Multiple DCs) } \\ \text { Facebook Esbjerg - Denmark (planning underway for potential Multiple }\end{array} & \begin{array}{l}\text { Additional hyperscale data centres from } \\ \text { DCs) }\end{array} \\ \begin{array}{l}\text { HIVE Blockchain Technologies, Ballangen - Norway (announced } \\ \text { acquisition), Sweden (acquired Hydro 66) }\end{array}\end{array}$

Note: The companies are selected by similarity in investment type, which does not mean that they would have a specific interest in investing in the region. This applies for indicated all potential investments. Municipal and private developments of suitable DC sites are ongoing in all the Nordic countries.

* Developers like i.e BULK infrastructures and Statkraft are making sites available for build in Norway.

\subsubsection{Cloud (Build for purpose)}

Cloud (Build for purpose) are facilities owned and operated by the cloud companies, which deliver XaaS computing services. ${ }^{1}$ The larger cloud providers build multisite regional setups with a range of availability zones to secure low latency and high reliability in the service. The client base for the cloud companies are all corporate, governmental and individual's applications. This has the aspiration of supporting both mission-and life critical applications, security and uptime. An overview of the Nordic investment in cloud (build for purpose) data centres is exemplified below.

${ }^{1} \mathrm{XaaS}$ is a general, collective term that refers to the delivery of anything as a service. It recognizes the vast number of products, tools and technologies that vendors deliver to users as a service over a network. 
Table 2: Overview of Nordic investments in cloud, build for purpose

$\begin{array}{ll}\text { Current investments } & \text { Potential investments } \\ \begin{array}{l}\text { Google, Hamina - Finland (Multiple Data centres installed, potential } \\ \text { extensions announced possible) }\end{array} & \text { Microsoft* } \\ \begin{array}{l}\text { AWS, Eskilstuna, Västerås \& Katrineholm - Sweden (Multiple site Cloud } \\ \text { Region announced under construction) }\end{array} & \text { Alibaba Cloud } \\ \begin{array}{l}\text { Google, Fredericia - Denmark (site lot planned for potential Multiple DCs) } \\ \text { Google, Avesta - Sweden (site lot planned for potential Multiple DCs) }\end{array} & \text { Rackspace } \\ \begin{array}{l}\text { Google, Aabenraa - Denmark (Ha site lot planned for potential Multiple } \\ \text { DCs) }\end{array} & \text { OVH } \\ & \text { Oracle } \\ & \text { Iron Mountain } \\ & \text { SAP, T-systems, Digital Ocean, Centurylink } \\ \end{array}$

Note: The companies are selected by similarity in investment type, which does not mean that they would have a specific interest in investing in the region. This applies for indicated all potential investments.

* Microsoft recently announced 2 Cloud regions in Norway in Stavanger and Oslo (no self-build announced).

** Based in colocations in the region, IBM have a range of own DC sites in the Nordic region.

\subsubsection{Colocation (Retail \& Wholesale)}

This segment consists of a data centre owner selling space, power and cooling to multiple cloud, enterprise and hyperscale customers in a specific location. By supporting the above segments, as well as growing demand from enterprises, the need for high security and uptime guarantee is of great importance in design. This is why the design of backup power supply has been vital historically. The large colocation providers typically have multisite setups in the metro areas of operations. An overview of the Nordic investment in colocation data centres is exemplified below. 
Table 3: Overview of Nordic investment colocation

Digiplex, Oslo, Stockholm and Copenhagen (Operating multiple sites in these 3 Nordic capitals, announced further activities in the countries and in Finland)

Equinix, Stockholm, Helsinki and Espoo (Operating multiple sites)

Advania (2 locations in Iceland)

Etix Everywhere Borealis (3 location in Iceland + Etix in Sweden)

Interxion, Stockholm and Copenhagen (Operating multiple sites in these 2 Nordic capitals)

Telia, Helsinki - Finland

Green Mountain, Stavanger Region - Norway (multiple sites in operation in the region, recently announced extensions)

Hydro 66, Boden-Sweden

BULK, Oslo

Verne Global, Keflavik - Iceland

Global Connect/Broadnet, multiple sites Denmark \& Norway (in operation)

Lefdal Mine, Måløy - Norway (Old mine facilities)

Hetzner - Finland

DC Finland

Orange-Norway

HermanlT - Finland

Ficolo - Finland

Bahnhof, Vodafone (IS), IBM, Availo, Sungard, Colt, Hetzner, KMD, IBM, NNIT, Nokia, Storespeed, ECODC, Fortlax, Availo, IP-only, TNNet, and

Bolooba (announced)
Digital Realty trust

Global Switch

China Telecom

AtHubs,

GDC

NTT (a range of regional companies)

China Mobile Intl

Telehouse KDD

Cyrusone

Cyxtera

21 Vianet

Switch

Keppel

STT

Colt

JD.com

Edgeconnex

Orange

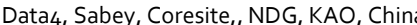

Unicom, Cologix, Zayo, GPX, AIMS;

CloudHO,

Additional colocation from current investors

Note: * The companies are selected by similarity in investment type, which does not mean that they would have a specific interest in investing in the region. This applies for indicated all potential investments.

\subsubsection{Enterprise}

Enterprise is a segment of a data centre facility, owned and operated by the company it supports. It is often built on-site, however in certain cases it could also be off-site. In recent years, enterprises have to a large extent made use of the professional services 
offered by cloud and colocation service companies and have focused efforts on their core business. This segment includes all types of companies from small size to large Fortune 500 companies, conglomerates, "exponential organizations", unicorns etc. An overview of the Nordic investment in the enterprise segment is exemplified below.

Table 4: Overview of Nordic investment in enterprise

Ericsson, 2 sizable sites in Linköping and Stockholm - Sweden for R\&D purposes

The trend in this segment that to a large degree companies have outsourced their DC investments and let Cloud and Colocation companies take care of these services and seek to focus on their core businesses

Fujitsu (in Helsinki)

The investments from Enterprises in selfbuild Data centres are to come from large corporates so from a foreign investment strategy the focus here should be on attracting large financial institutions or Industrial, i.e loT heavy industries as Car manufacturers

Danish Meteorological Institute in Iceland

Oslo DCLo (HPC, 4 locations planned, Follumoen DC operating)

CGI (5 Helsinki), Tieto (Vantaa), CSC (Kajaani, scientific HPC)

New investments are foreseen primarily from financial institutions like

Nordea, DNB, SEB, Danske Bank, OP corp, Sampo and a few large

corporates like: H\&M, SKF, Vestas, Yara, Nokia, Volvo, IKEA and Maersk

\subsection{Development of the FLAP-D market}

International connectivity, in particular proximity to internet exchanges and other peering hubs is seen as a major decision factor to attracting data centre investments. Traditionally when addressing data storage and transition geography, there are cities and regions of special mention as the hubs of the infrastructure; i.e the Virginia cluster, New York, Miami, Dallas in the US, Singapore, Shanghai, Tokyo and Hong Kong in Asia and FLAP in Europe. Frankfurt, London, Amsterdam and Paris have in recent years been followed by Dublin as a strong region of attraction for international data centre investments.

A large share of the European data centre investment is currently concentrated around the Tier 1 cities of the FLAP markets, most noticeable in the colocation and cloud segments. Dublin is also a growing location for data centres in all categories. Enterprise and especially colocations have until now mainly chosen FLAP-D, but have also made investments in the Nordics. Cloud investors have also been more active in FLAP-D during the past years. 
Figure 5 below illustrates power capacity as of 2018 in the FLAP-D markets. London has the overall highest IT load, whereas, Dublin has the highest hyperscale load.

Figure 5: FLAP-D hyperscale and colocation (MW IT load).

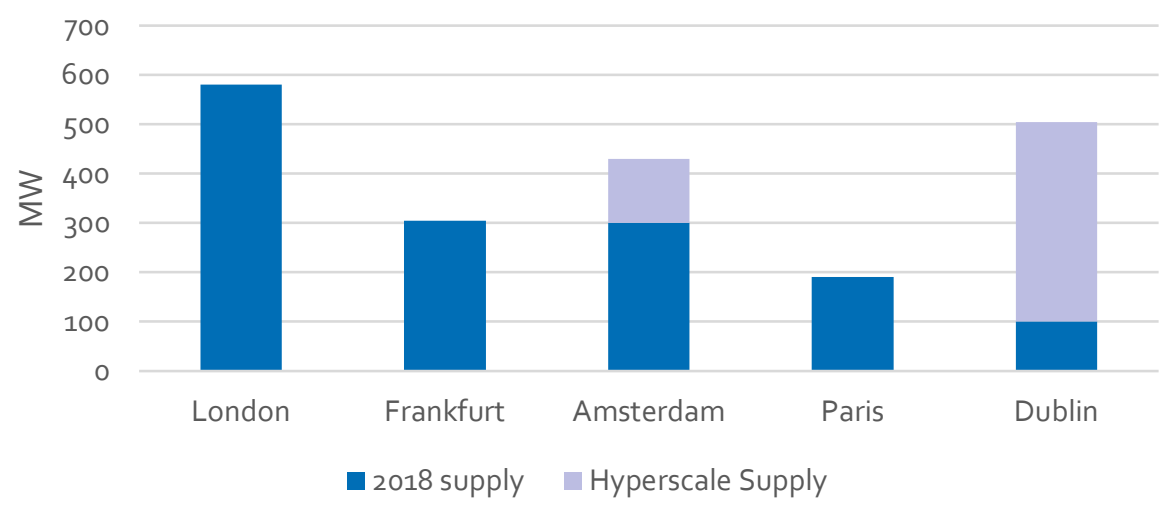

Note: The segmentation above in colocation and hyperscale also include cloud providers as mentioned in this report terminology.

Source: JJL 2018.

This FLAP-D segment as a whole, amounts to approximately $2000 \mathrm{MW}$ of installed base, with projections to grow significantly in the coming years. ${ }^{2}$ Historically these developments build on: ${ }^{3}$

- London: Corporate HQs, Financial European power house;

- Frankfurt: Financial services, Eastern gateway and local data protection schemes;

- Amsterdam: Continental connectivity hub, time to market;

- Paris: Mainly increased outsourcing and Regional/domestic demand;

- Dublin: EMEA HOs, corporate tax, US connectivity.

As a result, a group of prominent investors have already built their data centre facilities in the FLAP-D markets including: Google, Facebook, Microsoft, AWS, IBM, Equinix, Digital Realty Trust, NTT, Keppel, Interxion, Alibaba, Global Switch, Telehouse KDDI, Cyrusone, Cyxtera, Switch, STT, Colt, Edgeconnex, OVH, Iron Mountain, and KAO etc.

${ }^{2} \mathrm{~A}$ range of different sources: i.e JLL, CBRE, Bitpower/Host in Ireland.

3 A range of different sources: i.e Broadgroup, CBRE. 


\section{Strengths and value proposition of the Nordic region}

The Nordic region is a global leader in the digital economy. The citizens of Denmark, Sweden, Norway, Finland and Iceland are actively engaging in a multitude of online services, including business digitalization and e-commerce activities. Hence the Nordic countries head the EU Digital Economy and Society Index (DES/4). For example, some Nordic nations from the region already in 2018 are adopting $5 \mathrm{G}$ networks, which will amplify further the digitalization of industries and the loT. The region has developed Long-Term Evolution (LTE) infrastructure and has a high penetration of fibre broadband services both domestically and internationally, which gives opportunities for businesses to develop data analytics and the loT innovations. Moreover, the percentage of Nordic enterprises using cloud computing services is the highest in Europe, as illustrated in Figure 6.

Figure 6: Nordic and FLAP-D adoption of cloud computing ( $\%$ of enterprises)

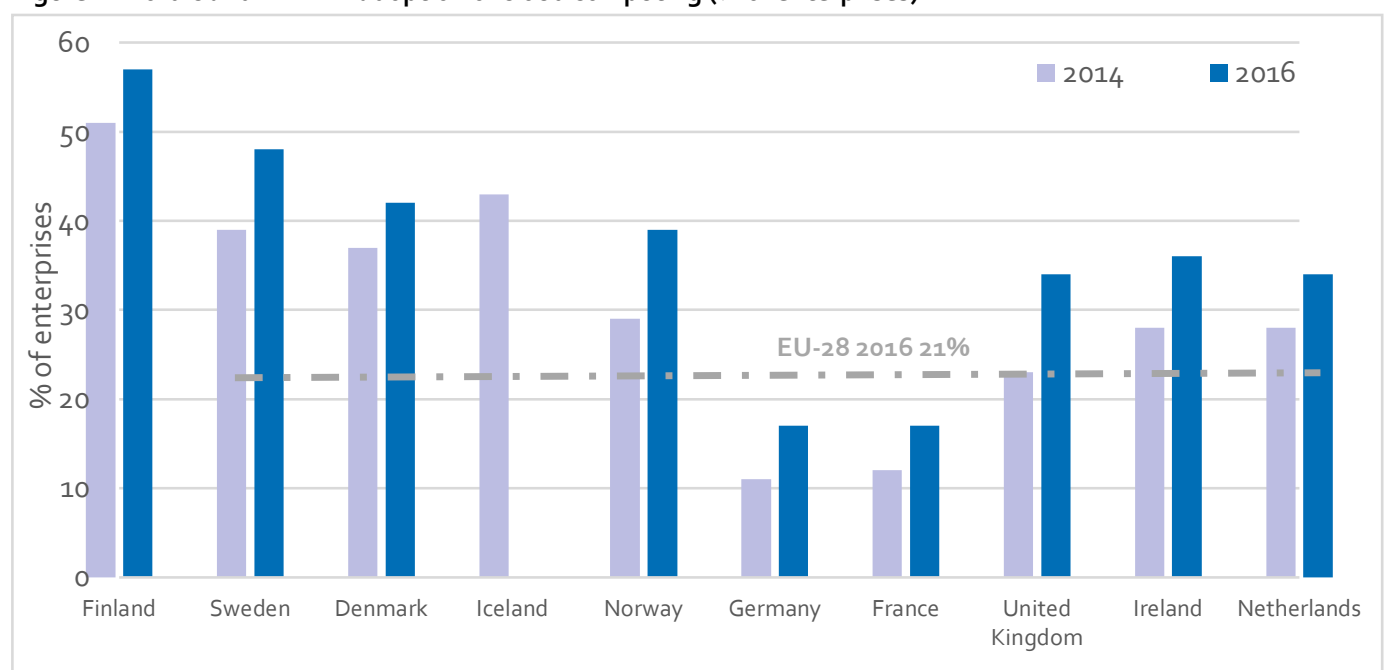

Source: Eurostat

https://ec.europa.eu/eurostat/statistics-explained/index.php/Cloud_computing_-

_statistics_on_the_use_by_enterprises

The Nordic public sector is playing a key role in digitalizing the region. For example, Nordic governments have adopted e-Government strategies aiming to spur the digitalization of public administration, making printed forms or letters redundant, 
creating new welfare services and spurring the sharing and reuse of available public sector solutions and data. This public sector digitization could provide a strong growth environment, as it will make it easier to run a business. Hence the administrative burden from reporting to public authorities is removed through automatic business reporting and thus reducing costs for both the public and private sector. Nordic governments are also preparing strategic guidelines for big data. The guidelines are proposing to concentrate on removing the restrictions of the data economy development in order to better utilize the potential of digitalization. Additionally, with the decline of domestic cash use, some Nordic central banks consider to issue digital currency. Such policies are anticipated to drive further the exploration of $\mathrm{HPC}^{5}$ and blockchain based solutions, which will create even more demand for digital infrastructure, such as data centres.

The Nordic countries have an outstanding "human capital" with above $90 \%$ of the population being regular internet users. In this context, the workforce in some of Nordic countries have the highest proportion of ICT specialists in the EU relative to its population. Similarly, the Nordic region is characterized with a growing share of enterprises using cloud computing (in fact, the highest in Europe). The increasing number of enterprises in the cloud for business operation, information storage and stronger computing power continues to grow. Additionally, there are a number of initiatives which explore digital technology solutions in the areas of smart mobility, ehealth, smart lighting, smart energy, extended user experience and more.

The Nordic region's global leadership in digitalization provides the foundation of an attractive business opportunity for DC operators and investors. In order to materialize this opportunity, there are a number of factors impacting the costs and risks of data centre owners. COWI has identified 16 "factors of importance" which impact the decision for DC site location. Those factors can be grouped into the following four categories:

- Energy factors such as reliability of the power supply, low energy prices, the abundance of energy \& other resources, the availability of renewable electricity supply and other innovative energy solutions for reducing OPEX;

- Connectivity factors such as the links with other regions through networks and fast data connections, proximity to international airport, and closeness to customers;

- Nature given factors such as cool temperatures and natural disaster-free climate;

- Other business factors such as time-to-market, taxes and duties, the access to affordable land with opportunities for space scalability, the availability of competent workforce, political stability and long-term predictability.

Aligned with these four groups of factors, a desk study provides evidence that the Nordic countries are having an overall advantage when compared to FLAP-D markets. For example:

$5 \mathrm{HPC}$ generally refers to the practice of aggregating computing power in a way that delivers higher performance. 
When it comes to the energy factors - they are crucial to data centre decision makers as they have a strong impact on the associated costs and risks of data centre investments. Energy is one of the areas in which the Nordic countries have a significant advantage from a European and even global perspective.

For example, the Nordic region is characterized with its high reliability of energy supply with some of the best-performing grids in Europe. For the period 2002-2016, the average annual planned and unplanned outage times in the Nordic region were rarer in the range of $20-150$ minutes, when compared to $30-168$ in the FLAP-D region. ${ }^{6}$ This implies that the reliability of the grid and power supply in the Nordic region could result in a lower risk of interruptions of the data centre operations due to power outages.

Moreover, when the grid reliability is combined with attractive electricity prices which for industrial consumers are significantly lower in the Nordics (ranging between EUR 0.06-0.10 per kWh, against EUR 0.08-0.15 per kWh in the FLAP-D region)7, the value of the Nordic region emerges even further. Please note that these prices are indicative and presented only for overall benchmarking purposes. Individual prices could be even lower as reports suggest EUR $0.03-0.04$ per $\mathrm{kWh}$ in the Nordic region.

Furthermore, the Nordic region has an abundance of clean energy resources. For example Denmark has plenty of biomass and wind power, Norway and Sweden have a lot of hydropower, Iceland has geothermal energy and Finland biomass. In this context, the Nordic region is a global leader in clean energy with renewable energy consumption in the order of $32-98 \%$, against $6-16 \%$ for the FLAP-D region. This is another important factor for the majority of hyperscale data centre investors. ${ }^{8}$ Nordic deregulated wholesale and retail power markets make it easy for corporates to directly purchase renewable energy to their data centres via PPAs etc. With the growing focus on sustainability, the Nordic region thus becomes increasingly attractive due to its high share and abundance of renewable resources.

In terms of international connectivity, there is no single parameter which can be used for comparison. Growth in digital traffic has made connecting with multiple networks characterized by higher speed connection, lower latency and high security desirable. As seen in below Figure 7, the Nordic region is currently differentiating itself from the FLAP-D region by adding new fibre links to markets in the US, Asia and Europe, aiming to attract global traffic routes via the North. A vital benchmark is the specific latency between users and data exchanges, which comes down to distance, and terrestrial and submarine cables connecting the world. As visible in the illustration presented below showing the international connectivity through subsea cables, both the Nordics and FLAP-D regions are well connected. This being said, it is evident that currently the FLAP-D through its heritage holds the largest data exchange services in the EMEA region.

Other parameters for benchmarking could be global indexes such as the GSMA Mobile Connectivity Index (which is built for the wider international community to

\footnotetext{
${ }^{6}$ Based on data by the Council of European Energy Regulators (CEER).

7 Electricity prices for non-household consumers, second half 2017 (EUR per kWh) (Eurostat, 2018).

${ }^{8}$ Share of renewables in energy consumption in the EU reached $17 \%$ in 2016 (Eurostat, 2018).
} 
deliver on the ambition of a universal internet and the mobile industry). This index in 2018 ranked the Nordic countries much higher, with a score in the range of $66-80$, as compared to $58-72$ for the FLAP-D region. This demonstrates strong performance of the Nordic region.

Another indicator could be the Global Connectivity Index 9 , which encompasses the entire chain of ICT development and digital transformation to provide a 360 -degree view of the digital economy building on four pillars (supply, demand, experience and potential). The index tracks 40 indicators which are key enablers that will drive the next wave of economic benefits resulting from ICT investment including in broadband, data centres, cloud services, big data and loT. According to the 2018 ranking of the Global Connectivity Index, all Nordic countries are positioned within the top 10 worldwide with scores in the range of $65-73$ (against $61-70$ of the FLAP-D region which spans in top 20).

Figure 7: Submarine cable map 2018

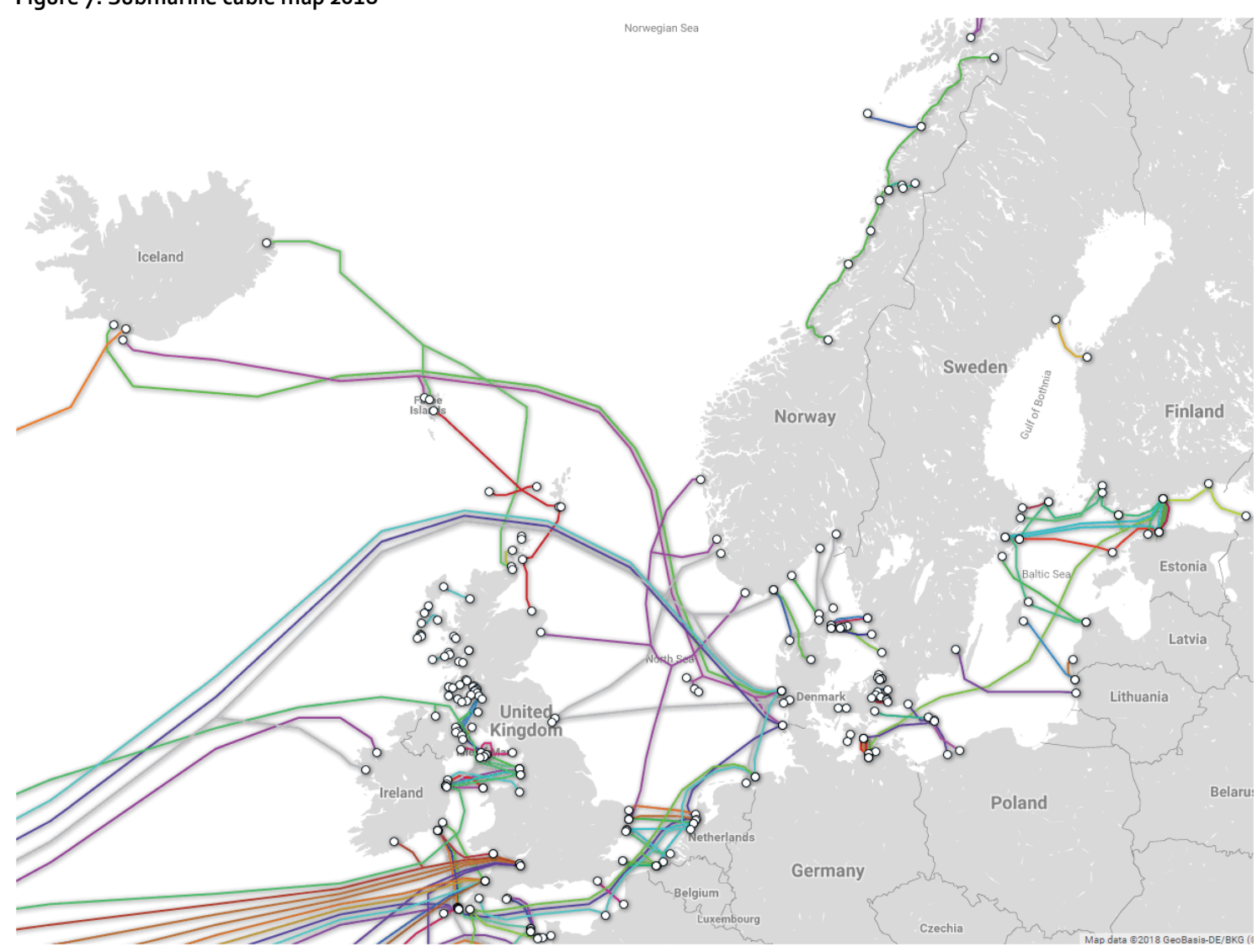

Note: The grey cables are "in planning".

Source: Submarine Maps 2018.

9 GCI Ranking Table 2018. 
When it comes to nature given factors, the relative cold locations in the North help data centre owners and operators optimize costs for power and cooling (Table 5). This enforces further the attractiveness of the energy factors such as reliable power supply and abundance of renewable energy resources at competitive prices.

Table 5: Climate data on FLAP-D and various Nordic sites, average monthly temperature in ${ }^{\circ} \mathrm{C}$

\begin{tabular}{|c|c|c|c|c|c|c|c|c|c|c|c|c|}
\hline & Jan & Feb & Mar & Apr & May & Jun & Jul & Aug & Sep & Oct & Nov & Dec \\
\hline Reykjavik, Iceland & 0.7 & 0.4 & 0.9 & 3.4 & 6.7 & 9.8 & 11.7 & 11.1 & 8.5 & 4.6 & 2.2 & 0.6 \\
\hline Tromsø, Norway & -3.3 & -3.2 & -2 & 1.6 & 6 & 9.3 & 12.6 & 11.5 & 7.8 & $3 \cdot 3$ & 0 & -1.8 \\
\hline Dublin & $5 \cdot 3$ & 5.5 & 6.6 & 8.1 & 10.7 & 13.2 & 15.2 & 15 & 13 & 10.3 & 7.4 & 5.4 \\
\hline Luleå, Sweden & -8.4 & -9.2 & -4.6 & 0.7 & 7 & 12.8 & 16.2 & 14.4 & 9.1 & 2.8 & -3 & -6.5 \\
\hline Billund, Denmark & 1.1 & 1.2 & 3.2 & $7 \cdot 3$ & 11.1 & 13.8 & 16.5 & 16.3 & 13 & 8.8 & 4.7 & 1.7 \\
\hline Amsterdam & 3.7 & 4.1 & 6.5 & 9.7 & 13.1 & 15.5 & 17.8 & 17.7 & 15 & 11.3 & 7.2 & 4.1 \\
\hline Oslo, Norway & -2.6 & -2 & 1.2 & 6.4 & 11.4 & 15.2 & 17.9 & 16.9 & 12.4 & 6.6 & 2.2 & -2 \\
\hline Helsinki, Finland & -4.8 & $-5 \cdot 4$ & -2.3 & $4 \cdot 3$ & 10.2 & $14 \cdot 3$ & 18.2 & 16.1 & 11.8 & 6.2 & 1.9 & -1.9 \\
\hline London & 5.8 & $5 \cdot 4$ & 8 & 9.7 & 13 & 15.8 & 18.8 & 18.5 & 15.8 & 12.8 & 8.7 & $7 \cdot 4$ \\
\hline $\begin{array}{l}\text { Stockholm, } \\
\text { Sweden }\end{array}$ & -1.6 & -1.5 & 1.3 & 6.7 & 11.7 & 15.6 & 19.2 & 17.8 & 13.2 & 7.6 & 3.6 & 0 \\
\hline Frankfurt & 1.9 & 2.8 & 6.5 & 10.2 & 14.2 & 17.7 & 20.2 & 19.8 & 14.9 & 10.3 & $5 \cdot 4$ & 2.4 \\
\hline Paris & $5 \cdot 3$ & 5.9 & 9.1 & 12 & $15 \cdot 5$ & 18.5 & 20.5 & 20.3 & 17.4 & $13 \cdot 3$ & 8.5 & 5.6 \\
\hline
\end{tabular}

Source: Ashrae Meteo (2017).

In terms of other business factors, the Nordic economies have a regulatory environment which is conducive to the starting and operation of a local firm. The Nordic region is characterized by ease of doing business, swift and agile authority handling of zoning and local planning, dealing with construction permits, getting electricity and registering a property which involves less procedures and thus associated time and costs savings. These are some of the findings also from the World Banks' Doing Business Ranking, which scores the Nordic region with a better average aggregated ranking of 11 , as compared to 21 for FLAP-D. ${ }^{10}$ Additionally, the Political Stability Index 2018 ranks the Nordic region high on indicators such as political stability and absence of the likelihood that the governments will be destabilized or overthrown by unconstitutional or violent means ${ }^{11}$. The predictability of the Nordic political structure is thus also playing a role in making the region attractive for foreign investment.

\subsection{Ranking of most important factors for site selection}

COWI has collected and assessed data regarding the most important factors that key decision makers consider before selecting a location for their future data centres (no matter the region). The decision makers perform due diligence considering a variety of

\footnotetext{
10 The World Bank, Doing Business Ranking 2018.

${ }^{11}$ The political stability index 2018 is an average of several other indexes from the Economist Intelligence Unit, the World Economic Forum, and the Political Risk Services, among others.
} 
factors, which could have an impact on their final cost and the associated risks on the potential data centre investment.

While there are many factors to consider, COWI found that factors perceived as most important for selection of data centre locations are:

1. "Reliable power supply" and "international data connectivity";

2. "Low energy prices";

3. "Political stability";

4. "Time-to-market", "abundance of energy and other resources", "competent workforce" and "natural disaster-free climate".

Figure 8 illustrates the importance of all major factors for selecting a data centre location - scored on a scale of 1 to 10 (10 indicates the most important). The figure shows that energy factors points out as the most important factors for site selection.

Figure 8: Most important factors for selection of data centre locations (scored on a scale from 1-10)

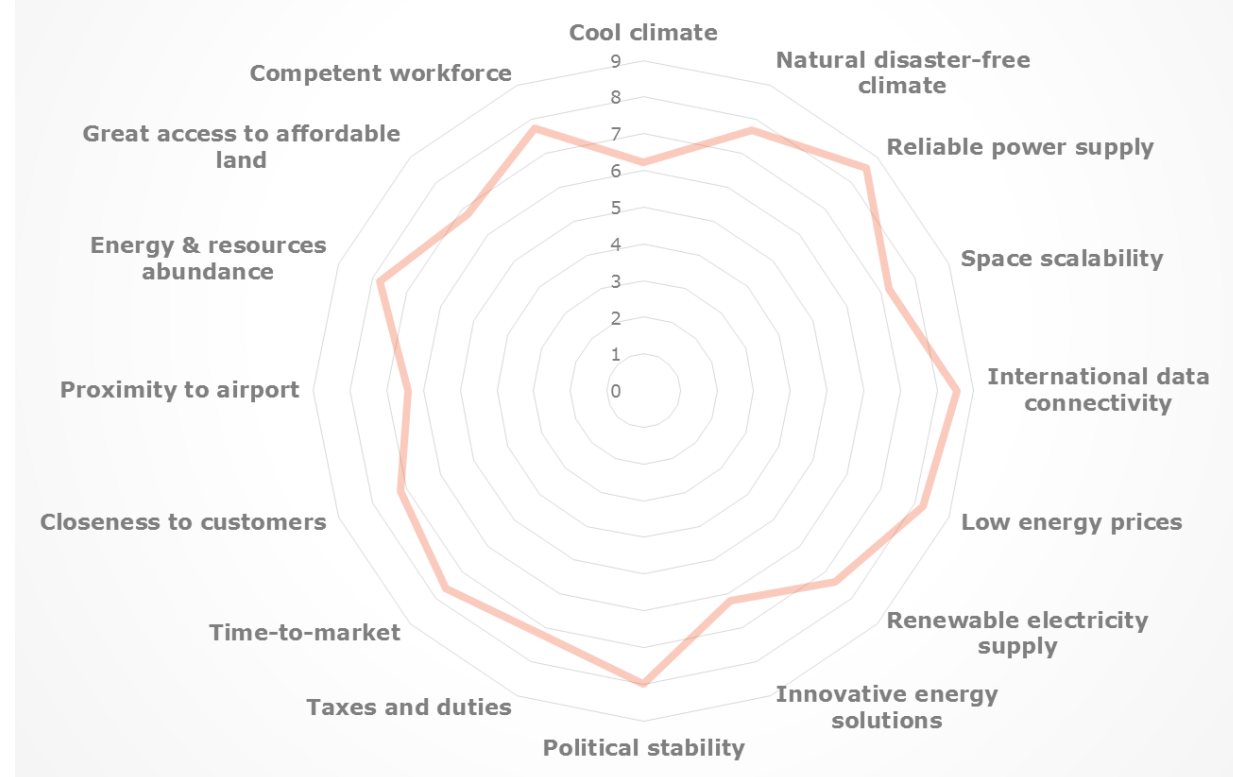

Source: COWI, Analysis of Data Centre Investment Opportunities in the Nordic Countries (2018).

In the $30+$ interviews conducted during the study, the interviewees in addition scored the importance of the factors according to the different types of data centres (Figure 9). This provided the following ranking of factors, split into the four DC segments: hyperscale, cloud, colocation and enterprise on a scale of 1 to 10 (10 indicates the most important). 
Figure 9: Importance of factors for different types of data centres (scored on a scale from 1-10)

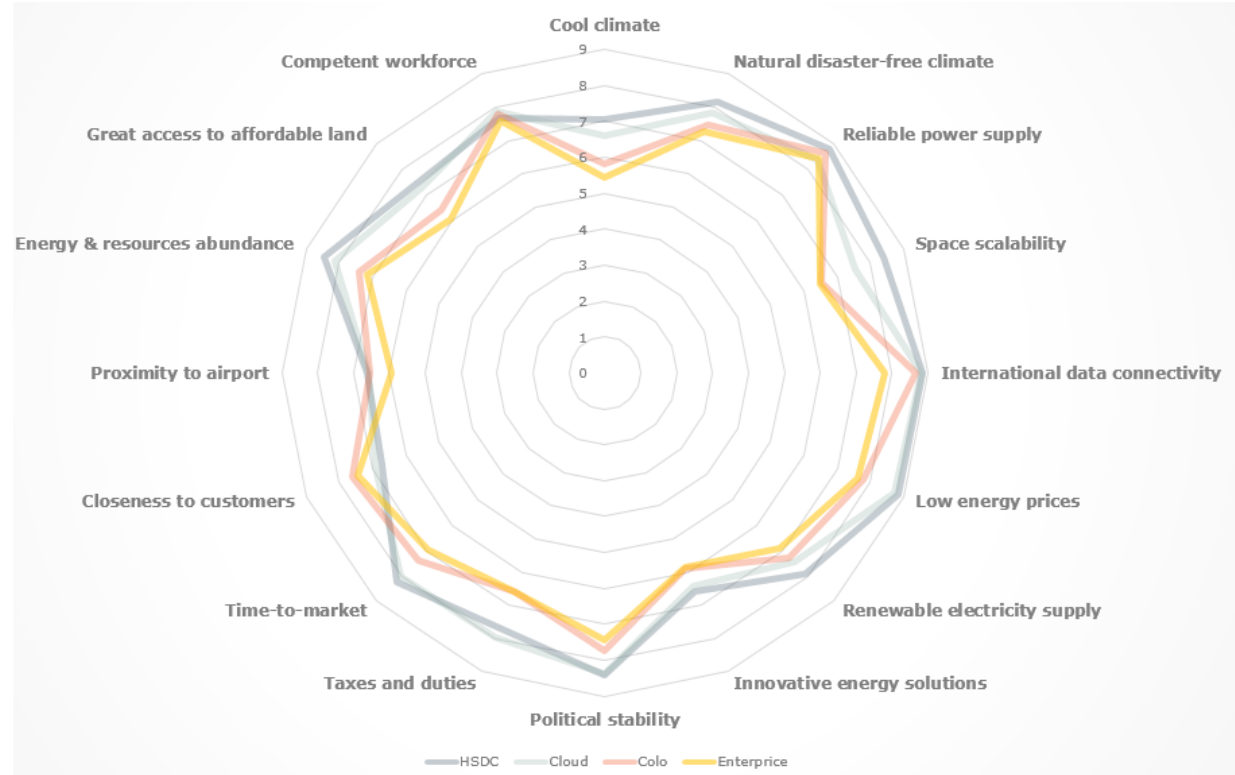

Source: COWI, Analysis of Data Centre Investment Opportunities in the Nordic Countries (2018).

It appears that the key finding of the differentiated scoring is, that hyperscale (HSDC) facilities score highest on almost all parameters, except closeness to customers. Therefore, in order to attract investment in hyperscale facilities, almost all factors appear very important and need to be satisfied. To some extend this could be explained by the fact, that the investment amount in a hyperscale facility is larger and will require more resources and due diligence to minimize the risks. The hyperscale segment appears to compromise only in terms of "closeness to customers".

Table 6 below provides a detailed numerical overview of the factors importance per segment. 
Table 6: Ranking of importance factors to each data centre segment

\begin{tabular}{|c|c|c|c|c|c|c|c|}
\hline HSDC & & Cloud & & Colo & & Enterprise & \\
\hline International data connectivity & 8.9 & International data connectivity & 8.8 & Reliable power supply & 8.7 & Reliable power supply & 8.4 \\
\hline Low energy prices & 8.8 & Low energy prices & 8.7 & International data connectivity & 8.7 & International data connectivity & 7.8 \\
\hline Reliable power supply & 8.8 & Political stability & 8.4 & Competent workforce & 7.8 & Low energy prices & 7.6 \\
\hline Energy \& resources abundance & 8.5 & Reliable power supply & 8.4 & Low energy prices & 7.8 & Competent workforce & 7.6 \\
\hline Political stability & 8.4 & Energy \& resources abundance & 8.1 & Political stability & 7.7 & Closeness to customers & 7.4 \\
\hline Space scalability & 8.4 & Time-to-market & 8 & Closeness to customers & 7.6 & Political stability & 7.4 \\
\hline Time-to-market & 8.2 & Taxes and duties & 8 & Natural disaster-free climate & 7.5 & Natural disaster-free climate & $7 \cdot 3$ \\
\hline Natural disaster-free climate & 8.2 & Competent workforce & 7.9 & Energy \& resources abundance & 7.4 & Energy \& resources abundance & 7.2 \\
\hline Renewable electricity supply & $7 \cdot 9$ & Natural disaster-free climate & 7.8 & Time-to-market & $7 \cdot 4$ & Time-to-market & 7 \\
\hline Taxes and duties & 7.7 & Space scalability & 7.6 & Renewable electricity supply & $7 \cdot 3$ & Renewable electricity supply & 6.9 \\
\hline Competent workforce & $7 \cdot 7$ & Renewable electricity supply & 7.5 & Taxes and duties & 6.6 & Taxes and duties & 6.6 \\
\hline Great access to affordable land & $7 \cdot 4$ & Great access to affordable land & $7 \cdot 3$ & Proximity to airport & 6.5 & Space scalability & 6.5 \\
\hline Cool climate & 7.1 & Closeness to customers & 6.9 & Space scalability & 6.5 & Great access to affordable land & 6 \\
\hline Closeness to customers & 6.7 & Cool climate & 6.6 & Great access to affordable land & 6.4 & Proximity to airport & 6 \\
\hline Proximity to airport & 6.6 & Proximity to airport & 6.6 & Innovative energy solutions & $5 \cdot 9$ & Innovative energy solutions & 5.9 \\
\hline Innovative energy solutions & 6.6 & Innovative energy solutions & 6.4 & Cool climate & 5.8 & Cool climate & $5 \cdot 4$ \\
\hline Average & 7.9 & Average & 7.7 & Average & 7.2 & Average & 6.9 \\
\hline
\end{tabular}

Source: $\quad$ COWI, Analysis of Data Centre Investment Opportunities in the Nordic Countries (2018).

It also appears that cloud data centres have similar scorings as the hyperscalers and the interpretations therefore are similar. The top five factors for hyperscalers and cloud segments are the same (though in a different order). Also, the five least important factors are the same (also in different order). Therefore, from a site selection perspective, hyperscale and cloud facilities could be considered together (even though they have different business models).

Colocations and enterprises appear similar as well. Some interviewees emphasized that dedicated enterprise data centres are expected to be replaced by enterprise data centres integrated in colocation facilities in the future. Moreover, both segments received a lower average score of all factors, but a higher score than hyperscalers and cloud on closeness to customers. Power issues and connectivity are also the most important factors for these two segments. Though, when compared to hyperscale and cloud segments, colocations and enterprises prefer to be closer to their customers. Other major differences are that colocation and enterprise data centres tolerate better warmer climate and less space scalability.

\subsection{Value proposition of the Nordic region}

Considering the same factors important to senior management in companies owning and/or operating data centres, we have collected data on the attractiveness of the Nordic region and the FLAP-D markets. In the context of the most important factors outlined above, we found that in the Nordic region is ranked as very attractive in terms of: 
- Reliable power supply;

- Low energy prices;

- Political stability;

- Time-to-market;

- Abundance of energy and other resources;

- Scalability.

The FLAP-D received a more attractive score in terms of:

- International data connectivity;

- Availability of competent workforce;

- Taxes and duties (for Dublin only).

As a result, the value proposition of the Nordic region for all data centre segments, building on the most important site-selection factors for DC owners and operators is illustrated in Figure 10.

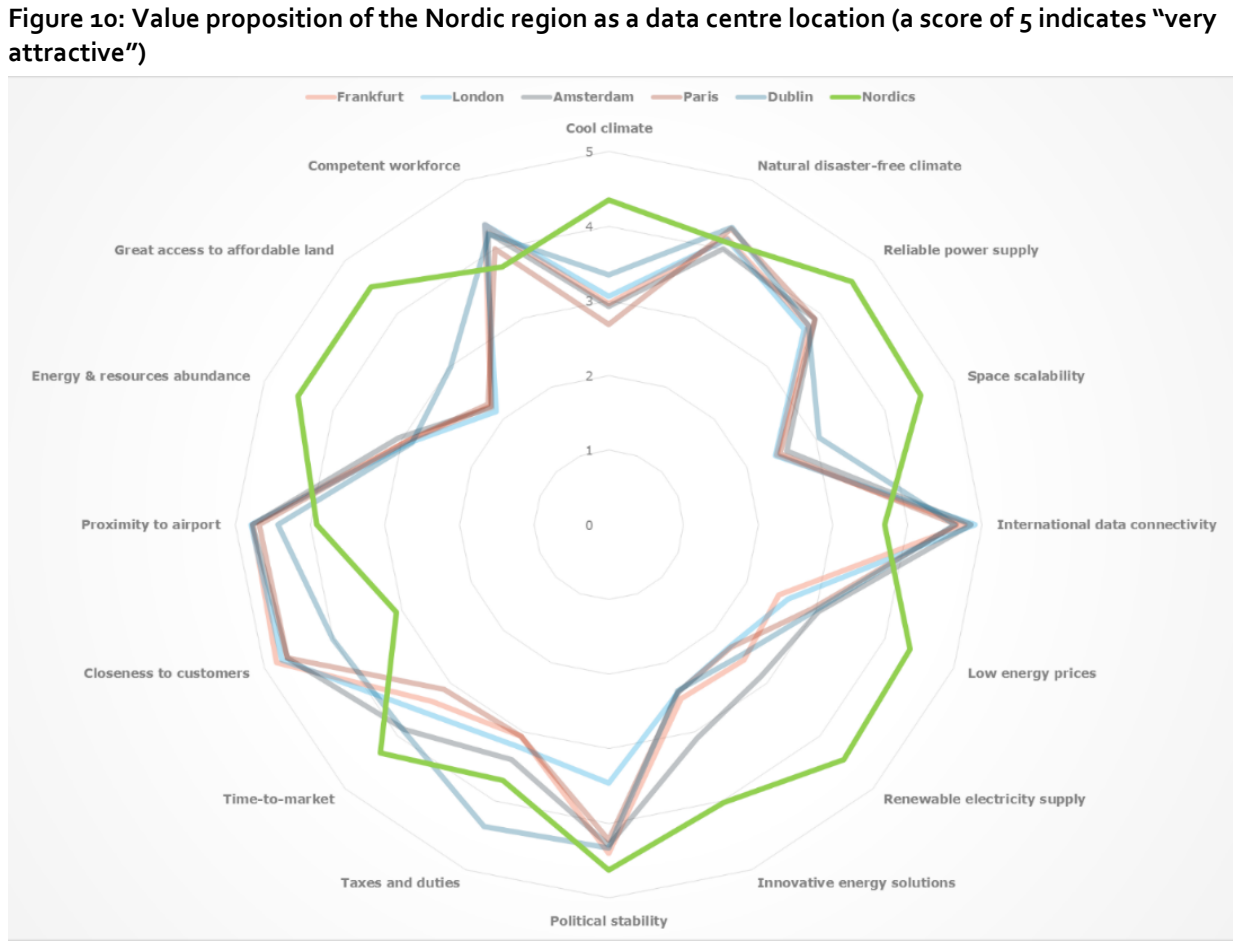

Source: COWI, Analysis of Data Centre Investment Opportunities in the Nordic Countries (2018). 


\subsubsection{Nordic value proposition for hyperscale and cloud}

The Nordic region appears very attractive for investment in the hyperscale and cloud segments according to the most important site-selection factors. When the most important factors for the hyperscale and cloud segments are compared with the attractiveness of the Nordic region under the same factors (Figure 10), it appears that the Nordic countries score very high. The vertical axis of Figure 11 illustrates the Nordic score ( 5 indicating very attractive) and the horizontal axis (10 indicating very important). As visible, there is a strong match on the top right quadrant (the most important factors are colored darker).

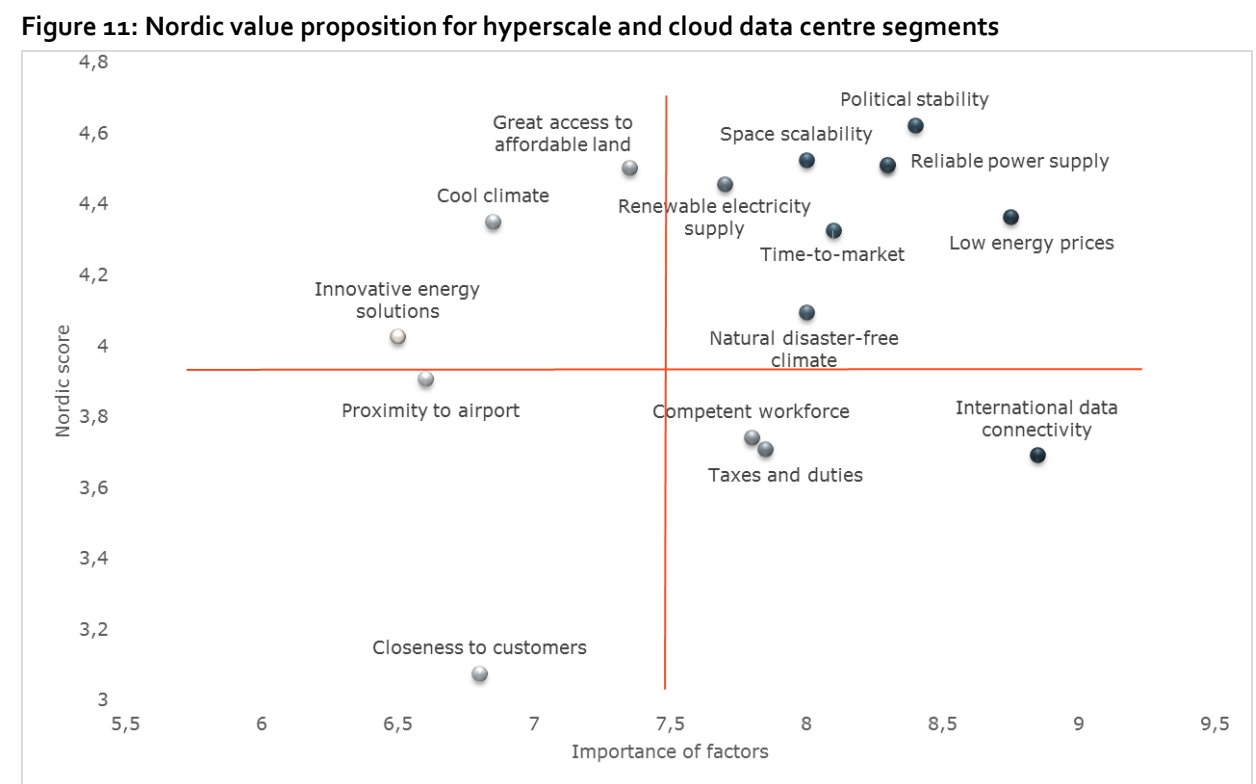

Source: COWI, Analysis of Data Centre Investment Opportunities in the Nordic Countries (2018).

Overall, the Nordic region seems to be a very attractive location for long-term hyperscale and cloud investors. The time to market, space scalability and the energy related factors are very important to the hyperscalers and the Nordic region scores very high on all of them.

Maintaining a reliable, renewable and cost-efficient electricity system, combined with political stability and short time to market also contribute significantly to the Nordic region's value proposition. Space scalability is a function of both low population density and planning acts. The low population density is probably permanent, whereas it requires political focus to maintain planning acts allowing for upscaling of data centres. Additionally, access to affordable land, a cool climate and innovative energy solutions are notable Nordic attraction parameters. They are not perceived that important, but also have a role to play.

Closeness to customers is one of the factors where the Nordics score lower, but this seems less important for hyperscalers and cloud investors (when compared with the 
other two segments). Other factors in which the Nordics score lower are international connectivity, availability of competent work force and tax levels.

\subsubsection{Nordic value proposition for colo and enterprise}

The Nordic region appears attractive for investment in the colocation and enterprise segments according to the most important site-selection factors. The major difference between hyperscalers and cloud on the one side, and colocations and the enterprise data centre segments on the other, is that the latter segments score the importance of the majority of factors lower. This implies that even though the Nordic region is attractive on those parameters, they are less important for those two segments (Figure 12).

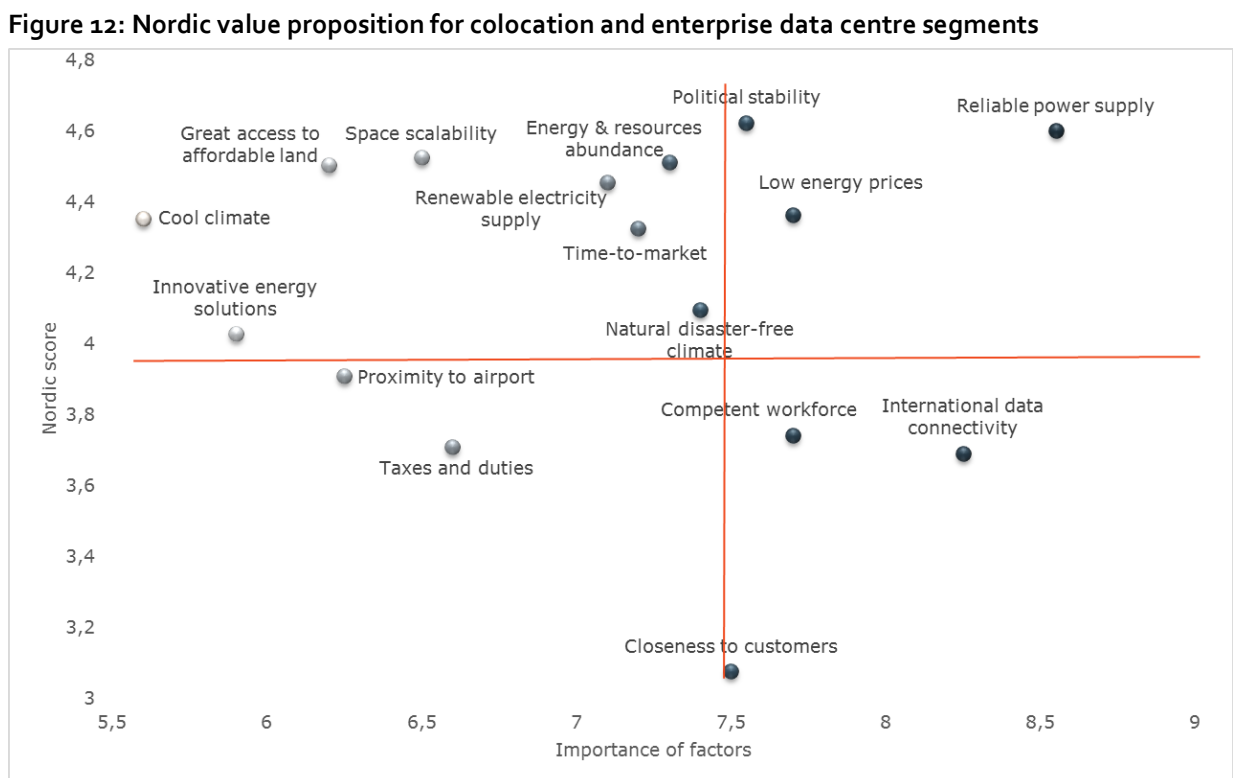

Source: COWI, Analysis of Data Centre Investment Opportunities in the Nordic Countries (2018).

This provides an opportunity for the Nordics to attract additional colocation and enterprise data centres. For instance for HPC DCs and colocation investors specialized in sustainability and low cost, the Nordics can appear very attractive. Moreover, with the rise of loT and autonomous cars we can also expect to see "edge" facilities in the metropolitan Nordic areas. With the advanced progress on digitalization, the Nordics provide opportunities for establishing homogeneous test environments and show cases.

We expect the demand of future colocations to increase in the Nordics, both due to growth in data generation and the increasing needs of hosting services for Nordic enterprises. The Nordic countries have the opportunity to focus on attracting larger colocations, which have sustainability as part of their business model. Similarly, as with the hyperscale and cloud segments, improved connectivity and education of workforce and tax regimes in favor of DCs can improve the framework for attracting collocation investments. 


\section{A growing opportunity for investment in the Nordics}

The Nordic countries present unique conditions for operating data centres amplified by a reliable power supply, abundant access to renewable energy at competitive cost and easy-to-do business environment. While important for all data centre segments, such factors reduce costs and risks and are crucial to attracting hyperscale and large cloud investment.

Our data centre investment outlook on activities in the Nordic countries identifies:

- In the short-term, upcoming data centre construction with a potential additional power capacity of $280+M W$ to be operational within the coming years;

- In the long-term, a potential of an additional 2,500+ MW in data centre power capacity, as indicated in master planning activities. More than half of these projects have undergone planning process, while the remaining are in process.

COWI estimates that approximately EUR 2.2 bn. have been invested in the Nordics on initiated data centre construction works over the last 12-18 months. Mainly within hyperscale and cloud infrastructure. This number could exceed EUR 4 bn. annually within the next five to seven years as a result of increasing market demand and a pipeline of planned future projects, without explicitly defined time commitments ${ }^{12}$. This outlook should be viewed as a potential and includes investments in peripheral buildings, as for instance administration, power substations and buildouts for utilising excess heat in the district heating system. The outlook considers the construction investment in buildings, energy infrastructure and land. It does not take into account the investment in computer servers, storage and racks.

The price per MW of data centre capacity is in the range of EUR 3-7 million, depending on the data centre segment and the size of the facility. The overall tendency is that large facilities such as hyperscalers have a larger potential to move to the lower end of the range in the coming years due to economics of scale and innovative costoptimization solutions. Such planned Nordic data centre power capacity, if fully developed, would account for a significant addition to the European data centre capacity.

A Nordic 2025 outlook of the construction investment in data centre ranging between EUR 2-4.3 bn. annually is presented in figure 13 .

\footnotetext{
12 These estimates should be viewed as a future potential and not as a forecast as there are a variety of uncertainties and other possible factors into play. The estimates assume a stable global economic outlook (without a global recession/ financial crisis) and that the Nordic countries work together with the aim to turn the region into a global data centre hub.
} 
Figure 13: Investment in data centres in the Nordics (EUR bn.)*

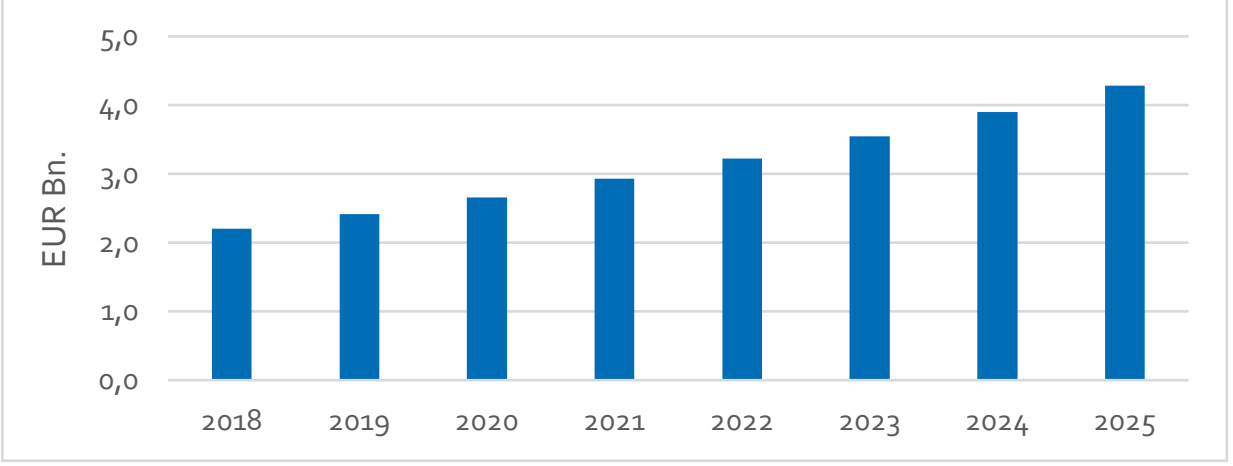

Note: * The outlook is in 2018 prices.

Source: COWI, Analysis of Data Centre Investment Opportunities in the Nordic Countries (2018).

A Nordic 2025 outlook of the power capacity in data centre with additions ranging between 280-580 MW annually is presented in Figure 14.

Figure 14: Power capacity of new data centres in the Nordics (MW)

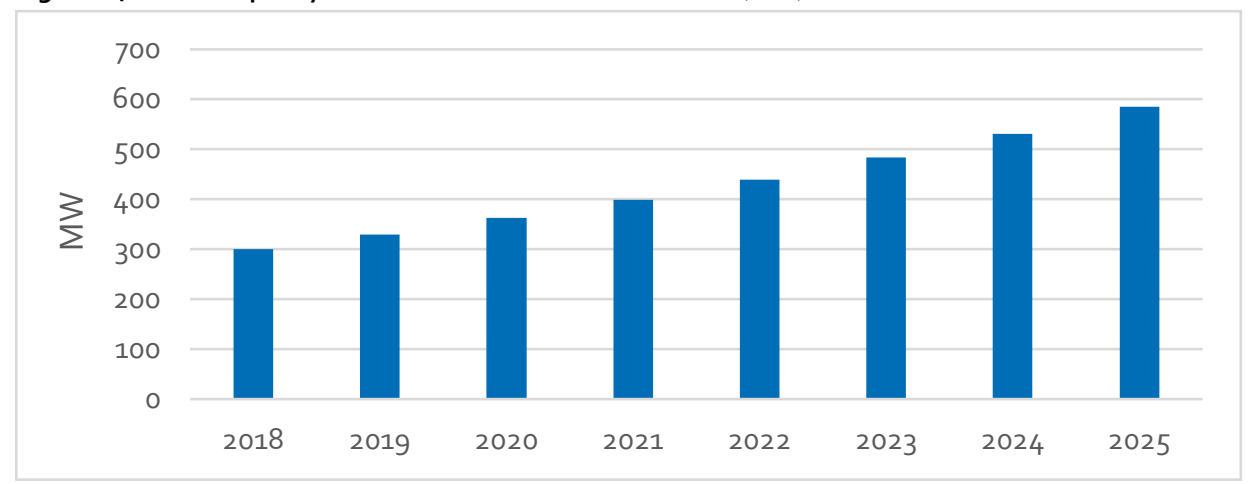

Source: COWI, Analysis of Data Centre Investment Opportunities in the Nordic Countries (2018). 


\section{Conclusions}

The world is seeing an exponential development in the need for processing and storing of data. This has resulted in significant investments in data centres throughout the globe. In recent years, the Nordics have seen a substantial increase in data centre investments. This is especially valid in connection with the planning and building of the infrastructure related to hyperscale facilities, where significant investments are already conducted and a number are under planning or construction.

The reasoning behind the selection of the Nordics as a preferred site for large data centre investment seems prudent. On a number of investor relevant parameters influencing the costs and risks associated with data centre investments, the Nordics appear very attractive. And the Nordics would have an even stronger investment case assuming that in the near future, investors further increase their focus on sustainability.

For large investments in the hyperscale and cloud segments, the Nordic value proposition seems to provide an exceptionally strong match. This includes fast time to market, space scalability and energy related factors. In relation to the colocation and enterprise segment, the many Nordic propositions seem of lesser importance. Closeness to the costumers is becoming less relevant when new fast connections are in place. Also, when the demand for more environmentally sustainable solutions arise, the relevance of the Nordics as a site for colocations and enterprise can increase further as well.

While overall the Nordic region is perceived as less connected than the FLAP-D markets, the Nordic region is well connected to the UK, continental Europe, and the US with many new fibre connections in planning over the next few years, including to Asia. Access to a polar fibre route from China is expected to cut Asia to Europe latency by half. In the coming years, we may be seeing the quickest routes to moving traffic globally via the Nordic countries, however this is not the current market perception yet.

From an operations perspective, the Nordic region continues to maintain a high demand for qualified talent while experiencing a slight employment shortage of technicians. Career tenures for data centre technicians tend to be longer than when compared with other European data centre markets. The Nordic region is furthering the supply of a qualified workforces with data centre dedicated courses for example from the Danish Technological Institute, the Regional academies of higher education and different trade organizations and many others. Other initiatives like for example the current cooperation between DC operators and Norwegian technical colleges also provide courses in "data centre infrastructure engineering". There is also a lot of Nordic R\&D activity with focus on data centre innovation, for instance RISE SICS North, which is the world's first open big-data research datacenter. 


\section{Literature}

Arctic Circle Cloud Services (2012). Pre-Feasibility Study-Arctic Cloud Data Centre.

BCG (2014). Digital Infrastructure and Economic Development. An Impact Assesment of Facebook's Data Centre in Northern Sweden.

BCG (2016). Digitizing Europe. Why Northern European Frontrunners Must Drive Digitization of the EU Economy.

BCG (2016). Capturing the Data Centre Opportunity, How Sweden Can Become a Global FrontRunner in Digital Infrastructure.

Bitpower (2017). Ireland's Data Hosting Industry 2017.

BroadGroup (2013). Iceland's competitive advantages as a global Data Centre location.

BroadGroup (2015). Data Centre Nordics.

BroadGroup (2016). Presentation: Data Centre Market Europe.

Business Sweden (2015). Presentation: Blue Skies with Green Clouds. Lighting Up the Nordic Datacentre Scene.

Business Sweden (2015). Advantage Sweden. Expanding to Sweden - Data Centres.

Business Sweden (2015). Presentation: Datacentre Market Update.

CBRE (2017). Europe Data Centres, Q2 2017.

CBRE (2018). 2018 KickStart Europe Outlook.

Copenhagen Economics (2017). Finland's economic opportunities from data centre investments.

Copenhagen Economics (2018). European data centres. How Google's digital infrastructure investment is supporting sustainable growth in Europe.

Copenhagen Economics (2015). The economic impact of Google's data centre in Belgium.

COWI (2018). Temaanalyse om store data centre, Energistyrelsen.

DatacentreDynamics (2017). The Future Data Centre. Trends in smart data centre design and construction.

Deloitte (2014). Digital Infrastructure in the Netherlands. Driver for the Online Ecosystem.

Dutch Datacentre Association (2016). Dutch Data Centre Report 2016. State of the Dutch Data Centres. The new foundation.

Interxion (2015). Presentation: The Nordics - Copenhagen and Stockholm.

Menon Economics (2017). Gevinster knyttet til etablering av et hyperscale datasenter i Norge.

Oxford Economics (2018). Google Data Centres: Economic Impact and Community Benefit.

Oxford Research (2016). Analyse til understøttelse af investeringsfremmestrategi i Viborg Kommune.

Oxford Research (2015). Finland's Giant Data Centre Opportunity. From the Industrial Heartland to Digital Age.

Oxford Research (2015). Notat om Lollands muligheder for at tiltrække data centre.

Place Consulting (2015). 3 Mega Data Centre investments in Nordic countries - a comparison. Business Attraction Management in Nordic Cities and Regions.

Schneider Electric (2017). Presentation: IT division.

Stoller, Bill (2018). Cyrus One Throws Down the Gauntlet With Zenium Deal in Europe. Data Centre Knowledge.

Sweco (2017). Effekter av Facebooks etablering i Luleå - En studie av effekter på regional och nationell nivå.

JLL (2018). https://data-economy.com/dublin-to-become-biggest-european-data-centremarket-in-2019/ 


\section{Resumé}

Norden er en digitalt førende region og Danmark, Sverige, Norge, Finland og Island er kendetegnet ved befolkninger hvor over 90\% er jævnlige internetbrugere.

I de senere år har Norden tiltrukket et betydeligt antal datacenter investeringer. Det omfatter betragtelige investeringer fra "cloud" og "hyperscale" investorer som Facebook, Google, AWS og Apple. Således har Facebook netop offentliggjort potentielle udvidelser i både Sverige og Danmark mens AWS er ved at etablere tre nye datacentre i Stockholms området. Apple arbejder på to meget store sites i Danmark. Google udvider aktiviteter i Finland og har opkøbt arealer i både Danmark og Sverige. I Norge har Microsoft offentliggjort investeringer i to Cloud regioner og både private og offentlige aktører udviklinger områder til fremtidig brug for datacentre. I Island er nogle af verdens største high-performance computing (HPC) og blockchain data centre blevet etableret grundet adgang til billige fornybare energikilder og et køligt klima. Endelig udvider såvel både europæiske og nordisk orienterede cloud investorer deres aktiviteter i Norden.

Denne analyse søger at afdække de muligheder, der ligger for datacenter investeringer i Norden. Analysen undersøger investeringspotentialet i Norden og udviklingen i datacenter markedet i Norden sammenlignet med andre markeder. Den undersøger også hvilke styrker og fordele som Norden kan tilbyde, gennem at rangere de mest vigtige investeringsfaktorer fra investorsynspunkt inden for fire specifikke sektorer. Konklusionen er, at der er et meget stærkt match mellem de højst prioriterede faktorer, og hvor Norden vurderes at have et særlige styrkepositioner. Således er Norden fortsat et meget oplagt sted for yderligere datacenter investeringer i de kommende år.

Med afsæt i denne konklusion samt den generelle vækst i data center markedet vurderer COWI at de samlede årlige investeringer i datacentre i Norden i 2025 vil ligge mellem 2 og 4.3 milliarder EUR. Det svarer til udbygning af en datacenter kapacitet på årligt mellem 280 og $580 \mathrm{MW}$.

Studiet omfatter 16 individuelle nøglefaktorer som påvirker beslutninger i forbindelse med valg af arealer til etablering af Datacentre. Her konkluderer analysen at de vigtigste er følgende: 
1. "Energimæssig forsyningssikkerhed" og "internationale data forbindelser".

2. "Lave energipriser".

3. "Politisk stabilitet".

4. "Implementeringshastighed fra beslutning om investering er taget", "Rigelighed på ressourcer herunder energi", "adgang til kompetent arbejdskraft" samt et "klima med minimal risiko for naturkatastrofer".

Studiet peger samtidig på at Norden vurderes at rangere særligt højt i forhold til energimæssig forsyningssikkerhed, lave energipriser, politisk stabilitet, implementeringshastighed fra beslutning om investering er taget, ressourcerigelighed og muligheder for udvidelse. Således fremkommer fem stærke nordiske tilbud til datacentre branchen:

1. Energimæssig forsyningssikkerhed - da det nordiske energinet er ekstremt robust, hvilket minimerer risikoen for nede-tid i de ydelser som datacentrene leverer.

2. Lave energipriser - understøttet af et meget velfungerende og konkurrenceudsat marked for energi med væsentlig lavere driftsomkostninger.

3. Politisk stabilitet - kendetegnet ved transparens, forudsigelighed og konsensusbaserede beslutningsprocesser, som tilsammen reducerer risici ved langtidsinvesteringer.

4. Implementeringshastighed fra beslutning om investering er taget - støttet af et imødekommende erhvervsklima og hurtige godkendelsesprocedurer, hvilket betyder besparelser i tid og penge for virksomhederne.

5. Ressourcerigelighed herunder energi-eksempelvis fornybare energikilder så som biomasse, geotermi, vandkraft og vind.

I forhold til sammensætningen af de Nordiske styrkepositioner, gør det regionen særlig interessant for "hyperscale" og "cloud" segmentet. Dertil kommer at områder, hvor Norden også score højt, nemlig implementeringshastighed og udvidelsesmuligheder samt en række energirelaterede forhold også tæller meget positivt for hyperscale investorer.

Norden fremstår ligeledes som en attraktiv region for segmenterne "colocation" og "enterprise". Den væsentligste forskel i forhold til disse segmenter er, at de generelt scorer investeringsfaktorerne vigtighed lavere. Så til trods for at Norden har betydelige styrkepositioner vurderes dette altså mindre væsentligt. Det udgør altså en mulighed for Norden for at tiltrække yderligere investeringer inden for disse segmenter. Bevægelser inden for segmentet i Nordisk retning kan allerede ses inden for HPC og colocation investorer med fokus på bæredygtighed. Dertil kommer nye behov drevet af loT ("IT i alt"), selvkørende biler etc., der stiller nye krav om datacenter kapacitet ("edge") i særligt de Nordiske hovedstadsregioner. 
En yderligere styrkelse af den nordiske position og retningen mod at blive et internationalt knudepunkt for datacenterinvesteringer vil kunne underbygges gennem en indsats inden for:

- Internationale dataforbindelser: korte afstande til andre knudepunkter er en vigtig beslutningsparameter. En styrkelse af opfattelsen af den nordiske forbundethed baseret på fakta vil være relevant. Det drejer sig bl.a. om opgraderinger af søkabler mellem USA, Norge og Danmark i 2019, etableringer af en øst forbindelse (Stokholm-Finland), nye og eksisterende forbindelser mellem Danmark, Norge og Storbritannien. Finlands forbindelse til kontinental Europa gennem C-Lion, Danmarks forbindelse til Holland gennem COBRA samt Islands placering imellem og med forbindelse til to kontinenter. Endelige er der perspektiverne i en nordlig fiberforbindelse til Kina, der vil kunne have massive konsekvenser for datahastigheder til Fjernøsten.

- Adgang til arbejdskraft: tilgængelighed til rigelig og kompetent arbejdskraft er centralt for udviklingen af Norden som et knudepunkt. I takt med at data center industrien vokser frem stiger behovet for arbejdskraft. Opblomstringen af følgeindustrier til datacentrene betyder ligeledes en stigning i efterspørgslen efter lokal arbejdskraft med tekniske kompetencer. Det afspejler sig bl.a. i at de Nordiske lande er blandt de i Europa med den højeste andel af It specialister i arbejdsstyrken.

- Fortsat harmonisering af regler og procedurer på tværs af Norden: særligt godkendelsesprocedurer i forbindelse planlægning og byggeri, regler for fordeling af belastninger i elnettet samt køb af fornybar energi. Harmonisering styrker den samlede nordiske region yderligere og styrker mulighederne yderligere for at tiltrække datacenterinvestorer fra andre regioner. 


\section{Appendix A: Methodology}

The study has been conducted during the fall 2018 and in two phases. The first phase included mapping of the Nordic region and identification of importance / attraction parameters for investors. The second phase included mapping of the FLAP-D regions and benchmarking with the Nordic region.

The basis of the study consist of a desk study of existing DC related reports and stakeholder dialog (interview and survey) with both DC investors and independent DC experts.

The desk study of available reports had the purpose of creating a reference for investment trends in the Nordics and FLAP-D, as well as providing a perspective on the most relevant attraction parameters.

The stakeholder dialog consisted of an identification and outreach to more than 100 individuals having either management positions in companies investing in data centres or being independent experts on data centre development. Following a positive feedback either an interview were conducted by a senior consultant or subsequently a survey forwarded to the respondent. Only a small minority chose to reply to the survey.

In total data was received from 39 individuals, of which four (10\%) chose to reply through the survey.

Due to the nature of the report (addressing investment dispositions), the study provides complete anonymity to all interviewees. In the sourcing and screening of the interviewees it was ensured that representation of different DC sectors was achieved. The respondents thus had the following distribution according to segment.

Figure 15: Interviewed per segment

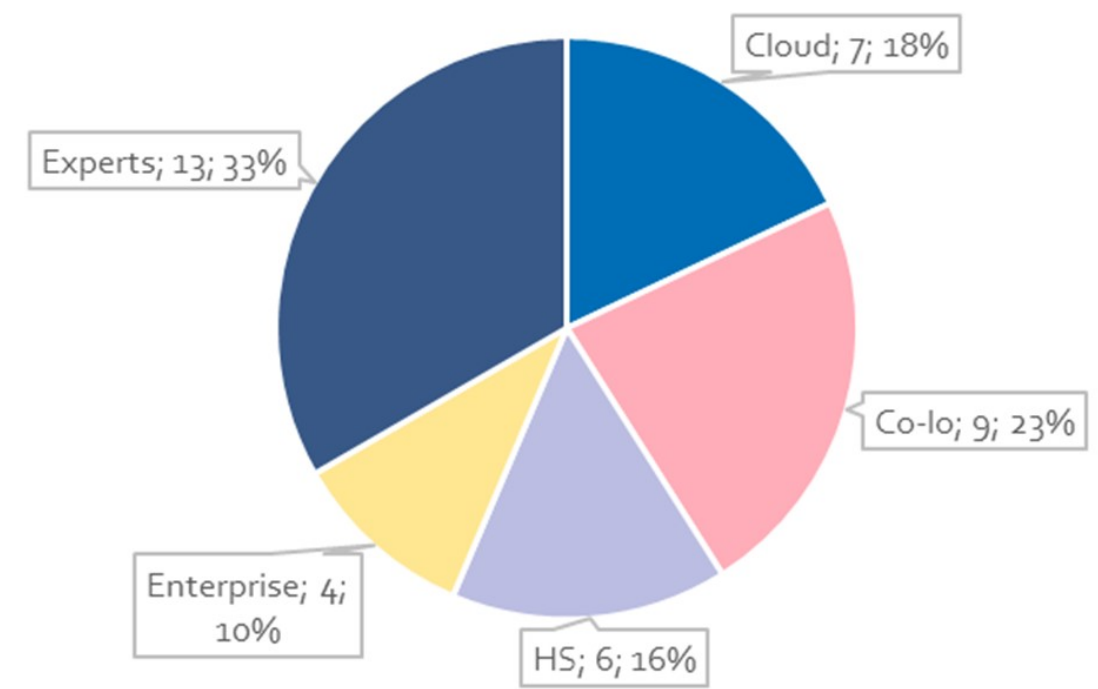

Source: COWI, Analysis of Data Centre Investment Opportunities in the Nordic Countries (2018). 
Conducting a qualitative data study based on interviewee experience and perceptions require treating stakeholder bias. Besides ensuring representation of the different identified DC segments, the independent experts were selected so that approximately half had experience from DC activities in the Nordics and the other half from FLAP-D. A number of interviewees had experience from both regions and/or other regions of the world.

Scoring of the general importance parameters, as well as the regional attractiveness was put to all interviewees - ensuring the highest possible number of responses and data entries. 


\section{Appendix B: Abbreviations}

\begin{tabular}{|c|c|}
\hline Al & Artificial intelligence \\
\hline AWS & Amazon Web Services \\
\hline bn. & Billion \\
\hline CBRE & Commercial Real Estate Services \\
\hline CEER & Council of European Energy Regulators \\
\hline CGI & Computer-generated Imagery \\
\hline COBRA & Copenhagen-Brussels-Amsterdam cable \\
\hline CoLo & Colocations \\
\hline CSC & Computer Sciences Coorporation \\
\hline DC & Data centre \\
\hline DCLo & Data Centre Location \\
\hline DESI & Digital Economy and Society Index \\
\hline $\mathrm{DL}$ & Deep Learning \\
\hline EMEA & Europe, the Middle East, and Africa \\
\hline EU & European Union \\
\hline EUR & Euros \\
\hline FLAP-D & Frankfurt-London-Amsterdam-Paris-Dublin \\
\hline GB & Gigabyte \\
\hline GCD & Game Developers Conference \\
\hline GW & Gigawatt \\
\hline $\mathrm{Ha}$ & Hectare \\
\hline HPC & High-performance computing \\
\hline $\mathrm{HQ}$ & Headquarters \\
\hline IBM & International Business Machines Corporation \\
\hline ICT & Information and communications technology \\
\hline IT & Information Technology \\
\hline loT & Internet of things \\
\hline kWh & Kilowatt hour \\
\hline LTE & Long-Term Evolution \\
\hline$M^{2}$ & Square meter \\
\hline $\mathrm{M} 2 \mathrm{M}$ & Machine-to-Machine \\
\hline $\mathrm{ML}$ & Machine learning \\
\hline MW & Megawatt \\
\hline NNIT & Novo Nordisk IT \\
\hline NTT & Nordisk Transducer Teknik \\
\hline PPA & Power purchase agreement \\
\hline
\end{tabular}


Research and development

SEB

Skandinaviska Enskilda Banken

SST

State Street Corporation

VR

Virtual Reality 
Nordic Council of Ministers

Nordens Hus

Ved Stranden 18

DK-1061 Copenhagen K

www.norden.org

\section{DATA CENTRE OPPORTUNITIES IN THE NORDICS}

The Nordic region attracts an increasing level of significant investments in new data centres. This seems to be no coincidence as the Nordics scores comparatively higher on factors such as "Reliable power supply", "Low energy prices", "Political stability", "Faster time-to-market" and "Abundance of energy and other resources" compared to more traditional European data centre regions. All factors that are deemed most important by data centre investors. This report estimates that the Nordics by 2025 could attract annual data centre construction investments in the order of EUR $2-4.3 \mathrm{bn}$. by 2025 . This is based on the forecast of the future demand worldwide for data centre services - as well as the strong value proposition of the Nordic countries towards large datacenter investments. 